CIRJE-F-1006

\title{
Measuring the extent and implications of corporate political connections in prewar Japan
}

\author{
Tetsuji Okazaki \\ University of Tokyo \\ Michiru Sawada \\ Nihon University
}

March 2016

CIRJE Discussion Papers can be downloaded without charge from:

http://www.cirje.e.u-tokyo.ac.jp/research/03research02dp.html

Discussion Papers are a series of manuscripts in their draft form. They are not intended for circulation or distribution except as indicated by the author. For that reason Discussion Papers may not be reproduced or distributed without the written consent of the author. 


\title{
Measuring the extent and implications of corporate political connections in prewar Japan
}

\author{
Tetsuji Okazaki* (Graduate School of Economics, The University of Tokyo, Tokyo, Japan) \\ and \\ Michiru Sawada $^{* *}$ (Nihon University College of Economics, Tokyo, Japan)
}

\begin{abstract}
This paper explores the extent of political connections of firms, and examines their implications on firm values, using firm-level data from prewar Japan. We collect the data of directors, their positions in the House of Representatives, stock prices and financial performance, on publicly traded companies in late 1920s and early 1930s Japan. It is found that almost $20 \%$ of the publicly traded companies had political connections through politician directors. Especially, firms in the regulated industries such as the electric power and railroad, were more likely to have political connections. Overall, there is no evidence that connections with politics added firm values. On the other hand, with respect to those firms that newly obtained political connections, we found that the stock returns improved from the pre-election period to the post-election period.
\end{abstract}

JEL Classification : G32, G34, G38, N25

Keywords: Political connection, Democracy, Election, Firm value, Japan

\footnotetext{
*E-mail address:okazaki@e.u-tokyo.ac.jp.

***-mail address: sawada.michiru@nihon-u.ac.jp
} 


\section{Introduction}

Anecdotal evidence from various countries in the present world indicates that firms with political connections can obtain benefits through preferential treatment for government procurement, easier access to public fund, tax exemptions, and so on. Motivated by these observations, a number of studies have addressed the issue of firms' political connections in the field of political science as well as economics. More specifically, many studies have investigated whether politically connected firms actually benefit from those connections (Khwaja and Mian, 2005; Faccio et al., 2006; Claessens et al., 2008; Goldman, 2013 among others). ${ }^{1}$

For example, Faccio (2006) examined the data of listed companies in 47 countries, to find that in 35 countries some firms are politically connected and that political connections add firm values, especially in the countries with weak political institutions. Also, Fisman (2001), Johnson and Mitton (2003), and Goldman et al. (2009) confirmed that political connections increase firm values in developed as well as developing countries. On the other hand, concerning newly privatized firms in China, Fan et al. (2009) revealed that political connections have negative effects on the post-IPO performance of firms. Thus, the empirical results on whether political connections add to firm value are mixed.

Recently a couple of articles studied this issue using historical data. Braggion and Moore (2013) investigated economic benefits of corporate political connections in Britain over the period 1895 to 1904 . They found that political connections increased stock returns of new technology companies and they benefited from easier access to external capitals through politician directors. Grossman and Imai (2014) utilized the data on British banks during 1879-1909, and confirmed that

\footnotetext{
${ }^{1}$ Khwaja and Mian (2005) and Claessens et al. (2008) investigate whether politically connected firms actually obtain preferential treatments for debt financing based on data collected from Pakistani and Brazilian firms, respectively. Faccio et al. (2006) examine whether politically connected firms are likely to be bailed out based on cross-country data. Goldman et al. (2013) analyze whether political connections affect government procurement contracts using data from the U.S.
} 
political connections did not increase on stock returns of British banks.

With the background of those literature, this paper investigates the extent and implications of political connections of firms focusing on prewar Japan. Prewar Japan has a number of attractive features for research on this issue. First, as we will see later, many firms indeed had political connections in prewar Japan. Political connections were much more pervasive in prewar Japan, compared with not only contemporary Japan and but also other contemporary countries.

Second, it is remarkable that democracy was fairly developed in prewar Japan. The Constitution of the Great Japan Empire, which was promulgated in 1889, prescribed the status of the Diet (Teikoku Gikai). Although the role of the Diet was formally limited to the support of the Emperor (kyosan), in reality the Diet had legislative power and the power to approve the national budget. The Diet was composed of the House of Peers (Kizoku-in) and the House of Representatives (Shugi-in), both of which had essentially the same powers. While the members of the House of Peers were appointed by the Emperor from peers, high tax payers, scholars, etc., the members of the House of Representatives were appointed by the public through a general election. Also, by the amendment of the Election Law in 1925, universal male suffrage was introduced, where all male citizens aged 25 and above had the right to vote in the general election.

Furthermore, in the late 1920s the authority of the House of Representatives increased, which was reflected in the de facto rule of appointment of the Prime Minister. Throughout the prewar period, the Prime Minister was officially appointed by the Emperor, and the appointment was based on the recommendation of a small number of informal political leaders called Genro, who were the people with merits in the Meiji Restoration. Within this system, from 1925, it was the de facto rule that Genro recommended the leader of the political party that had the majority at the House of Representatives as the Prime Minister, until 1932, when a military coup overthrew Inugai Tsuyoshi's cabinet (the May 15 Incident). In this sense, the period from 1925 to 1932 is regarded as the period 
of de facto party cabinet and the peak of democracy and party politics in prewar Japan.

In the literature of the Japanese political history, it is said that under this regime, the power and influence of political parties and Diet members increased in the wider domain of the society. Masumi (1979), a standard reference on Japanese political history, stressed that the relationship between the major political parties and private firms became closer during and after the WWI, because the political parties came to need more money for elections, while the private firms wanted to have connections with the political parties to obtain more political power (pp. 232-233). ${ }^{2}$ However, to the best of our knowledge, no study provides hard evidence about the effects of political connections on private firms in prewar Japan.

Hence, this paper investigates the political connections of firms, the changes in these connections before and after the general elections of February 1928 and February 1930 (the sixteenth and seventeenth general elections), and the implications of these connections. The 1928 General Election was the first general election after the universal male suffrage was established, and the 1930 General Election was that in the final phase of the de facto party cabinet system. In this sense, we explore the extent and implications of the political connections of firms at the peak of democracy and party politics in prewar Japan.

In the context of the Japanese economic history, the period from late 1920s and 1930s is characterized by a long depression and deflation, after the high growth in the late 1910s (Flath 2005; Nakamura 1994; Okazaki 1997). During WWI, new industries, including the metal, machinery, and chemical industries, developed rapidly based on the expanding capital market (Hamao et al. 2009). This enables us to use the stock price data as well as the financial data of a sufficient number of firms in various industries.

The rest of the paper is organized as follows. Section 2 describes the characteristics of political

\footnotetext{
${ }^{2}$ See also Masumi (1988, pp. 97-98).
} 
connections in prewar Japan. Section 3 explains the empirical methodology of this study, and Section 4 presents the empirical results. Section 5 concludes the paper.

\section{Identifying connections between firms and politics}

We identify the connections between firms and politics following Braggion and Moore (2013). They identified a firm as politically connected if at least one of the company directors is a member of parliament. ${ }^{3}$ In this paper, we identify a firm as politically connected if the firm had at least one director or auditor who was simultaneously a member of the House of Representatives. For the reasons stated in the introduction, we focus on the political connections of firms before and after the general elections in February 1928 and February 1930 (the sixteenth and seventeenth general elections).

The sample firms are those whose directorship data and financial data are available in the Kabushiki Nenkan (Corporate Stock Yearbook) edited by Osakaya Shoten, a major security company and the Ginko Kaisha Yoroku (Directory of Banks and Companies) edited by Tokyo Koshinjo, a major credit bureau, and whose stock price data are also available in Diamond, a major economic magazine published every ten days. Using the 1928 and 1930 issues of Kabushiki Nenkan and Ginko Kaisha Yoroku, we obtained the data about the directors and auditors of the sample firms just before the general elections in 1928 and 1930.

Diamond provides the stock price data of major companies every ten days. From this source, we constructed the dataset of the monthly stock prices of the sample firms. Since we want to calculate the stock returns for specific time windows (from 1 month to 5 months before and after the

\footnotetext{
${ }^{3}$ Faccio (2006) which is seminal work in the area, identified a firm as politically connected if at least one of the top officers or large shareholders either is a member of parliament or a minister or has a close relationship with a member of parliament or a minister. In this sense, our definition of political connections is narrower than that of Faccio(2006). This method is basically the same as that we used to identify connections between bank and firm and interbank connections (Okazaki, Yokoyama and Sawada 2005; Okazaki, Sawada and Wang 2007; Okazaki and Sawada 2012).
} 
general elections in February 1928 and February 1930), we collected the stock price data from August 1927 to July 1928 and from August 1929 to July 1930.

The information about politicians was taken from the Shugiin Meikan (Directory of the House of Representatives) by Nihon Kokusei Chosa-kai, which provides detailed information about the results of the general elections at the candidate level from 1890 to 1976. From this source, we obtained the list of the members of the House of Representatives who were elected in the general elections of 1928 and 1930. By matching the list of the politicians with the list of the directors and auditors of the sample firms for 1928 and 1930, we identified the politically connected firms after the general election of 1928 and 1930, respectively. The politically connected firms in 1928 and 1930 in this context are those that had at least one director or auditor who was elected in the general election of 1928 and 1930, respectively.

In order to identify the effects of political connections on firm values, we need to know the changes in the political connections within firms. That is, we want to know whether a firm already had political connections before the general elections in 1928 and 1930. Hence, we collected data on the political connections of firms before the general elections in 1928 and 1930, by matching the list of the firms' directors and auditors in 1928 and 1930 with the list of the members of the House of Representatives who were elected in the general elections in 1924 and 1928, respectively ${ }^{4}$.

Finally, from the samples we exclude those firms whose directorship data in the 1928 or 1930 issue of Kabushiki Nenkan is as of the time later than February of 1928 or 1930, respectively, because we want to focus on cases where the existing directors and auditors of the firms were elected to be Diet members. In addition, to reduce the effect of outliers, we exclude those firms whose monthly stock returns were higher than $100 \%$. Consequently, the samples included 398 firm-year observations—194 firms for year 1928 and 204 firms for year 1930.

4 The fifteenth general election was held in May 1924. 
Table 1 shows how pervasive the political connections were among the major firms in Japan in the 1920s. Panel A represents all the firms whose directorship information is available in the Kabushiki Nenkan; Panel B shows our sample firms defined above. In Panel A and Panel B, the rows classify the firms by their political connections after the elections, while the columns present the firms by their political connections before the elections.

Column 3 of Panel A-(1) shows that 176 of the 1,136 firms were politically connected after the elections (ratio: 15.5\%). Out of these 176 politically connected firms, 129 firms had been politically connected before the election as well, which implies that the political connections were consecutively retained. Splitting the sample for the years 1928 and 1930 (Panel A-(2) and A-(3)), we find that while the number of politically connected firms in the post-election period was 100 out of 559 firms (17.9\%) for 1928, the number of politically connected firms was 76 out of 577 firms (13.2\%) for 1930. That is, the percentage of politically connected firms decreased substantially from 1928 to 1930.

The results in Panel B about our sample firms are qualitatively the same as those in Panel A. Of the 398 firms in our samples, 78 firms (19.6\%) had political connections after the election. The ratio of politically connected firms in the post-election period in our sample is a little higher than that of the total major firms in Panel A. When we split the samples into those for 1928 and for 1930, the percentage of politically connected firms in the post-election period was $22.2 \%$ in the former, while it was $17.2 \%$ in the latter. As in Panel A, the percentage of politically connected firms in the post-election period declined substantially from 1928 to 1930.

We can compare the results of Panel B with the results reported in Faccio (2006), who used the data on publicly traded companies from 47 countries. According to Faccio (2006), in 2001, the ratio of politically connected firms to the total number of publicly traded firms was $1.34 \%$ in Japan and $2.68 \%$ in the world. That is, the ratio of politically connected firms in prewar Japan was much 
higher than that in contemporary Japan and the world. The ratio is close to the ratios in contemporary Indonesia (22.8\%), Malaysia (19.8\%), and Russia (20.0\%), where political connections are the most prevalent among the 47 countries that were studied. The difference in the extent of firms' political connections between prewar and contemporary Japan may reflect the difference in institutional quality. Faccio (2006) found that the incidence of political connections is higher in countries with political corruption and weak restrictions on political conflicts of interest. According to the recent corruption perception index compiled by Transparency International, present Japan is evaluated as a relatively clean country. ${ }^{5}$

Table 2 breaks down the results in Panel B of Table 1 by industry. We classify the sample firms into 13 industries according to the industry categories in Kabushiki Nenkan. The percentage of politically connected firms was higher in the electric utilities industry (45.0\%), the sugar industry (31.2\%), and the railroad industry (29.6\%). For public utilities industries such as the electric utilities and railroad industries, government licensing is generally important and so was in prewar Japan ${ }^{6}$. Ramseyer and Rosenbluth (1995) state that, according to the Light Railroad Subsidy Act amended in 1921, the Japanese government gave generous subsidies to private railroad companies, especially to small and unprofitable ones. Moreover, the government had immense influence on private railroad companies since it granted licenses. We can infer that firms in regulated industries such as the electric utilities industry and the railroad industry would have more incentives to build connections with politics because there were more rents in those industries than other industries ${ }^{7}$. Concerning the

\footnotetext{
${ }^{5}$ According to the corruption perception index of 2001, Japan ranks 21 out of 91 countries (http://www.transparency.org/research/cpi/cpi_2001). A high ranking indicates a lower level of perceived corruption.

${ }^{6}$ Agrawal and Knoeber(2001) pointed out that political connections in the electric utilities industry also were more important in contemporary U.S. during the 1990s when retail competition began. They confirmed that the incidence of political directors increased more than manufacturing industries during the period from1988 to 1999.Furtheremore, Boubakri et al.(2008) investigated newly privatized firms in 41 countries over the period from1980 to 2002, and found that firms operating in regulated industries were more likely to be politically connected.

7 Hara (1983) pointed out that some industries (including the public utilities industries and the
} 
high percentage of politically connected firms in the sugar industry, it is notable that companies in the sugar industry had many offices and plants in Taiwan, which was a Japanese colony in the prewar period. Therefore, we can infer that political connections were more important for firms which sought for the interests in the colony. ${ }^{8}$

Table 3 breaks down the results of Panel B of Table 1 by the position of the politician in the firm. The positions we consider are president, executive director, ordinary director, and auditor. ${ }^{9}$ Panel A of Table 3 reports the numbers and the percentages of politically connected firms by the position of the politician directors in their firms. While the number of firms where at least one of the ordinary directors or auditors was a member of the House of Representatives was 45 (11.3\%) and 28 (7.0\%), respectively, the number of firms where at least the president or one of the executive directors was a member of the House of Representatives was 10 (2.5\%) and 8 (2.0\%), respectively. Even when we examine the data by year, the results are similar. Hence, we can conclude that the firms tended to have political connections through ordinary directors and auditors rather than through presidents and executive directors.

Panel B of Table 3 reports the number of politician directors by their position in the firms. ${ }^{10}$ We find that the number of ordinary directors and auditors is much larger than that of presidents and executive directors. On the other hand, the percentage of politician directors among the total directors in each position was not substantially different across the positions. These observations suggest that the result in Panel A of Table 3 reflects only the difference in the number of people across the positions. Finally, the results for 1928 and 1930 show that the percentage of politician construction industry) that depended on public orders tended to have connections with politics (pp. 191-192).

${ }^{8}$ The results are similar if we use the data on all the firms in the Kabushiki Nenkan (Appendix Table 1).

${ }^{9}$ Some politically connected firms had multiple connections with politics. Therefore, the sum of the number of politically connected firms by four positions does not correspond to the total number of politically connected firms.

${ }^{10}$ Since some companies did not have a chairperson or a president, the number of top executives is less than the number of firms in our sample. 
directors decreased from $2.50 \%$ to $1.94 \%$ between these two years, which is consistent with the results in Table 1.

\section{Empirical strategy}

Using the samples described in the previous section, we examine how the political connections affected firm values. To examine the value of political connections, we compare the monthly stock returns of the politically connected firms and those of the non-connected ones. ${ }^{11}$ For the analyses, we should be careful about the endogeneity of firm's decision on political connections. That is, although the general election was exogenous to each firm, a firm's decision to make some of its board members run for the election may be correlated with the firm's characteristics and performance. Taking this potential endogeneity of political connections into consideration, we conduct the difference-in-differences (DID) approach. That is, we compare the differences in the stock returns of the politically connected firms (treatment group) and those of the non-connected firms (control group) between the pre-election period and the post-election period. To be specific, we estimate the following equation:

$$
B H R_{i t}^{n}=\alpha_{0}+\alpha_{1} P C_{i t}+\alpha_{2} P C_{i t} * \text { After }+\alpha_{3} \text { After }+\gamma^{\prime} \bullet X_{i t}+v_{i t}
$$

The dependent variable is the stock return of firm $i$. We measure the stock returns by the buy-and-hold returns (BHRs) using the monthly stock price data. The intervals to measure the BHRs are from one month to five months in both of the pre-election period and the post-election period ${ }^{12}$.

\footnotetext{
${ }^{11}$ It is difficult to conduct analyses based on daily stock returns due to data availability. The number of firms whose daily stock price information is available is much smaller than that of firms whose monthly stock price information is available.

12 If the interval to measure BHR is expanded, the number of sample firms are lost substantially due to data availability.
} 
Therefore, the dependent variable n-month $B H R^{n}{ }_{i t}$ indicates the n-month BHR of firm $i$ in time period $t$. For example, 3 month BHRs are either the BHRs for the 3 month before the election month or those after the election month. With respect to the explanatory variables, $P C$ is a dummy variable which takes the value one if a firm was politically connected in the post-election period, and zero otherwise. $P C$ firms include two types, that is, the firms which did not have political connections before the election but had the connections after the election, and those which continued to have political connections before and after the election. This dummy variable is used to capture the effect specific to the politically connected firms.

As the control group, we use those firms which had no political connections either in the pre-election or the post-election period. We do not include those firms which had political connections in the pre-election period but did not have them in the post-election, in the control group for the baseline regressions. The reason is as follows. Because those firms lost political connections through the election, the estimated effect of $P C$ is affected by the value of losing political connections if we include them in the control group ${ }^{13}$. As the value of losing political connections is interesting itself, we estimate the value of losing political connections later ${ }^{14}$.

After is the dummy variable which takes the value one if the observation is for the post-election period, and zero otherwise. The interaction term, $P C^{*} A f t e r$ is expected to capture the difference-in-differences effect of having political connections. If its coefficient is positive, political connections had a positive effect on firm value, and vice versa.

$X$ is the vector of other control variables. We use firm size (Size), ROA and debt ratio (Debt), industry dummies, and year dummy (Year 1928). The firm size is measured by the log of total assets. ROA and debt ratio indicate the return on assets (ROA) and the debt to asset ratio, respectively.

${ }^{13}$ We confirmed that the estimation results are qualitatively the same, if we added those firms into control group.

${ }^{14}$ We show the results of the value of losing political connections in Table 10. 
Iindustry-adjusted values of these variables, normalized by the industry average, are used in the estimation. Industry dummies are included to control for the industry specific effect. Sample firms are split into 13 industries, according to the industry categories in the Kabushiki Nenkan. The year dummy variable takes the value one if the observation is for year 1928, and zero otherwise. Our panel data consist of four time-periods, namely the pre-and post-election periods of years 1928 and 1930. In the estimation, we use the robust-standard errors clustered at the industry and year levels.

Table 4 reports the basic statistics. BHRs were not different between politically connected firms and unconnected firms (controls) in both the pre-and post-election periods. Politically connected firms had lower ROA and higher debt ratio than control firms, although the difference of ROA is marginally insignificant ( $p$-value=0.12). It can be interpreted that badly performed firms were more likely to have political connections. Firm size of politically connected ones was not statistically different from that of control firms.

\section{Estimation results}

In Table 5, we show the estimated results of baseline regressions. The dependent variables are from 1 month to 5 month BHRs, in columns 1-5 and 6-10, respectively. The results for the all sample firms are in column (1)-(5), and the results for the non-financial firm samples are in columns (6)-(10). In the regressions which we use all sample firms (columns (1)-(5)), the coefficients of $P C$ are negative and statistically significant in the cases of 2 months and 5 months BHRs, which suggests that firms which had political connections through the elections suffered from decreasing their values in stock market. The dummy variable, After has negative coefficients in all cases, which suggest that stock returns were lower on average in the post-election period than those in pre-election period. The interaction terms between $P C$ and After, which we are most interested in, are expected to capture the effects of having political connections in the sense of difference in 
differences. These coefficients are positive in all regressions, which suggest that firms increased their values by having connections with politics. However, these effects are not statistically significant. The coefficients of the year dummy variable, which indicates the observation is the sample of the year 1928, are positive and statistically significant. This result is considered to reflect the negative shock by the Great Depression in Japan (Showa Depression, 1930-1931). Other control variables are generally not significant, although the coefficients of debt ratio are partially significant (columns 1 and 3). The results of the regressions in columns 6-10, which use only non-financial firms, are similar with those of columns 1-5. In sum, we cannot find evidence that firms increased or decreased their values by having connections with politics through the election.

Overall, benefit of political connections was not confirmed in the baseline regressions. However, it is possible that the effects of political connections differed by industry, the financial condition of firms and attributes of politicians ${ }^{15}$. Hereafter, we examine these possible heterogeneity of the political effects by turns. First, we look at the heterogeneity by industry. As confirmed previously, political connections were more pervasive in the regulated industries such as electric utilities and railroad. As there are generally larger rents in the regulated industries, firms in the regulated industries might have more benefits through political connections (Hillman, 2005; Civilize et al. 2015$)^{16}$. To examine this possibility, we use the dummy variable, Regulation which takes the value one if a firm was in the electric utilities and railroad industries, and zero otherwise ${ }^{17}$. We interact this variable with $P C^{*}$ After to see the effect of political connections specific to the regulated industries.

15 For instance, Braggion and Moore (2013) found positive effects of political connections in new technology firms although no effects of political connections in all sample firms.

${ }^{16}$ Hillman (2005) and Civilize et al. (2015) found the value of political connections were higher in regulated industries, using the data on U.S. and Thailand, respectively.

17 We also used the different definitions of the regulation industries such as not only electric utilities and railroad industries but also financial industry or gas industry. However, we confirmed that the estimated results were not changed. 
The estimated results are presented in Table 6. The coefficient of the interaction term, $P C^{*}$ After*Regulation are negative and not statistically significant in regressions with all intervals of BHRs (columns (1)-(5)). The results are similar in the regressions for non-financials firms (columns (6)-(10)). Therefore, we have no evidence that the regulated industries obtained benefits through having connections with politics.

One possible interpretation of these results is that political connections had both positive and negative effects in the regulated industries. Actually, we found anecdotal evidence for positive and negative effects in prewar Japan. With respect to a positive effect, we can refer to a biography of Gorobei Ihara, who was an executive director of Ina Electric Railroad Co., which is in our sample firms. Ihara was a famous entrepreneur in Nagano Prefecture, who ran for the general election twice. Although he lost the election in 1915, he won the election in 1928. He decided to run for the election because he considered the best way to complete his railroad business was to become a politician (Miyasaka 1989, pp.18-21, pp.55-56). He seems to have had a clear intention of obtaining benefits for his business by becoming a politician. Another case indicating a positive effect is from the electric power industry. In 1911, electric power supply in Tokyo City was almost monopolized by Tokyo Dento, when some entrepreneurs including Mosuke Kawahara planned to find a new electric power company, Nihon Dento, and applied for the license to the Ministry of Postal Service and Telecommunication. As the Ministry was reluctant to giving the license for the reason that power supply was already enough in Tokyo City, Kawahara, who was a member of the House of Representatives, negotiated with the Ministry, and finally the license was given to Nihon Dento (Kawahara 1919).

On the other hand, there are anecdotes that indicate negative effects of political connections on firms in the regulated industries. One typical case was that of Tokyo Dento and Toho Denryoku, which were two of the major five electric power companies in prewar Japan and are in our samples. 
Shohachi Wakao was a member of the House of Representatives from 1917 to 1926, and a leader of Seiyukai, one of the two major political parties. Meanwhile, he was a famous business person. One of the companies he worked for was Tokyo Dento. He became a director of Tokyo Dento in 1917, and was installed as the vice-president in 1922. In this period there was harsh competition between major power companies. Although supply of electricity to a certain area needed a license of the Ministry of Postal Service and Telecommunication (Denryoku Seisaku Kenkyukai 1965, p.88), the Ministry often gave licenses for power supply to one area to multiple companies, unlike in postwar Japan. Since the late nineteenth century, Tokyo area was a base of Tokyo Dento, but another company, an affiliated company of Toho Denryoku, wanted to enter the Tokyo market and applied for the license to the Ministry of Postal Service and Telecommunication. This application was accepted in 1926, by the decision of the Minister, Kenzo Adachi, who was a leader of Kenseikai. Kenseikai was the other one of the two major political parties and in power then, and it is said that he intended to give a damage to Tokyo Dento, connected to Seiyukai. Then in 1927, when Seiyukai was in Power, the Ministry gave the license for power supply in Nagoya area, the base of Toho Denryoku, to Tokyo Dento ${ }^{18}$.

Second, previous studies suggested that political connections were more beneficial to financially distressed firms (Faccio et al., 2006;Acemoglu et al.2015). To examine this possibility, we add the variables on the firms' financial condition in the pre-election period. We use two firm's performance variables, namely, ROA and debt ratio. In the analyses of Table 7 and 8, the interaction terms of PC*After*ROA and PC*After*Debt are included in explanatory variables. In Table 7 , the coefficients of $P C^{*} A f t e r^{*} R O A$ are negative in cases of all intervals. In particular, those are statistically significant in the cases of the 2 months and 3 months intervals, for the samples of non-financial firms. Namely, firms with lower profitability obtained benefit from having political

${ }^{18}$ Kokumin Shinbun, June 5, 1934-November 3, 1934. 
connections. In table 8 , the coefficients of $P C^{*} A f t e{ }^{*}$ Debt are positive in most cases for all samples, which indicates that firm with higher risk obtain benefit from having political connections. However, they are insignificant. With respect to non-financial firms (columns 6-10), the coefficients of PC*After*Debt are positive in all intervals and slightly larger but still insignificant ( $p$-values are 0.124 in 2 month and 0.108 in 3 month). Although not always strong, there are partial evidence that firms with bad financial condition had more benefit by having political connections, which is intuitive.

Third, we turn to the attributes of politicians. On one hand, as experienced politicians were more likely to have influence on government policies, firms might get more benefits from having connections with those politicians ${ }^{19}$. On the other hand, it is possible that connections with experienced politicians have negative effects on firm values, because those politicians may be more likely to be involved in corruptions and political conflicts with other politicians especially those in opposite political parties. Also, it is possible that they have to spend more time for the government and parties, and are too busy to work for the firms ${ }^{20}$. To examine the effect of experiences of politicians, we introduce the dummy variable, Experience, which takes the value one if a firm has at least one politician director who had experience of winning in the past elections, and zero otherwise $^{21}$. In the estimation, the interaction term of $P C^{*} A f t e{ }^{*}$ Experience is added into

\footnotetext{
${ }^{19}$ In prervious studies, the value of political connections is higher with the level of political influence (Faccio 2006 and Civilize et al.2015).

20 This is consistent with the "business hypothesis" of corporate directors proposed by Ferris et al. (2003) which examine the effect of multiple directors. Grossman and Imai(2016) also interpreted the negative effects of the appointment of MP directors as being that these directors might have been less attentive to firm's affairs due to duties as a politician.

${ }^{21}$ We used personal index of members of the House of Representatives in Gikaiseido Hyakunen-shi (100-year history of parliamentary system) published by the Ministry of Finance, which provides information about which elections politicians won. We also checked whether politician directors in our samples were in more influential positions such as prime minister or other ministers. However, we confirmed that they were not in those positions in the government just after the elections that we analyzed.
} 
explanatory variables ${ }^{22}$.

The estimated results are shown in Table 9. While the coefficients of $P C^{*} A f t e r$ are positive and statistically significant in the cases of intervals from 1 month to 4 month, the coefficients of PC*After*Experience are negative and statistically significant in the intervals of from 1 month to 4 month $^{23}$. Namely the stock market negatively evaluated the experience of politician directors in the political circles. On the other hand, it is remarkable that if we control for the experience effect, the effect of having politician director on the firm value was significantly positive. That is, having a politician director who was new in the political circles, added firm value. With respect to a experienced politician, the negative impact almost canceled this positive effect, because the absolute values of the coefficients of $P C^{*} A f t e r$ and $P C^{*} A f t e{ }^{*}$ Experience are approximately the same.

The analyses so far regard all the firms that had political connections in post-election period as politically connected, and categorize those firms as PC. However, those firms includes two types of firms, namely, the firms which had political connections newly generated through elections, and the firms which had continued to have political connections in the pre-election and post-election periods. To examine the effects of these two types of political connections separately, we introduce two dummy variables, PC01 and PC11, as the explanatory variables, by splitting PC. PC01 takes the value one if a firm had no political connections in the pre-election period but had political connections in the post-election period, and zero otherwise. Meanwhile, PC11 takes the value one if a firm already had political connections in the pre-election period and had political connections in the post-election period as well, and zero otherwise. Furthermore, we introduce an additional firm

22 The intercept dummy Experience and the interaction term, Experience*After are not included in explanatory variables because $90 \%$ of politically connected firms $(P C=1)$ take the value one in the variable of Experience. Therefore, $P C$ and $P C^{*} A f t e r$ are considered to control the effects of Experience and Experience*After, sufficiently.

${ }^{23}$ We also conducted the same analyses using the number of winning in the past elections instead of the dummy variable, Experience. The coefficient of the interaction terms were negative but not statistically significant. 
category, namely the firms which had political connections in the pre-election period but did not have them in the post-election, in our samples, which are represented by a dummy variable, PC10. These firms are interpreted as those which lost political connections through the election. In the regressions, we include these three dummy variables (PC01, PC11 and PC10) and their interaction terms with the dummy variable After to capture the effects of these variables in the sense of difference -in-differences.

The estimated results are reported in Table 10. The coefficients of the dummy variable PC01 are negative and statistically significant with respect to from 2 month to 5 month intervals in the all sample firms (columns 1-5). This result indicates that firms which newly had political connections through the election, suffered from deteriorating firm values in the pre-election period, compared to the control firms. The coefficients of the dummy variable PC11 and PC10 are not statistically significant with respect to all intervals of BHRs. Therefore, stock returns of firms, which continued to have political connections and lost them through the elections, were not different from the control firms in pre-election period.

The interaction terms between the PC variables (PC01, PC11, PC10) and After are expected to capture the effects of political connections among each group. The coefficients of $P C 01 * A f t e r$ are positive and statistically significant in the cases of from 2 month to 5month BHRs (columns 2-5). Therefore, firms could obtain benefit from newly having connections with politics. According to the estimated coefficients in columns 4 and 5, stock returns of firms, which newly had political connections through the election, relatively increased by more $10 \%$ from the pre-to the post-election period, compared to the control group. The coefficients of $P C 11^{*}$ After are positive but not statistically significant. This result suggests that the firms that had political connections in both the pre-and post-election periods did not obtain additional benefits from continuing their connections with politics. Similar results are obtained with respect to the samples of non-financial firms 
(columns 6-10), although statistical significances of the effect of PC01*After is slightly weaker. Thus, we can say that firms obtained benefits from the political connections newly generated in the election.

In the same manner, the value of losing political connections can be measured by the coefficient of the interaction term between PC10 and After. Those coefficients are negative in case of the intervals of 1,4 and 5 month returns, but not statistically significant, which suggests that the stock returns of the firms which lost political connections through the election were not different from those of the control group, during the period from the pre-election to the post-election. Namely, there is no evidence that losing political connections causes firms to suffer from a decline in stock returns.

\section{Conclusion}

In this paper, we explored the extent of political connections of firms and examined their implications on firm values, using the firm-level data from prewar Japan. The period we focused on corresponds to the peak of democracy and party politics in prewar Japan. We defined a firm to be a politically connected, if at least one of its directors or auditors was a member of the House of Representatives.

We found that the percentage of politically connected firms was $19.6 \%$. This is much higher than the percentages in contemporary Japan and the world. This finding provides a hard and quantitative evidence for the view that influence of political parties increased in the business circles after the World War I, in the literature on the Japanese political history. We also revealed that firms in the regulated industries such as the electric power and railroad industries, were more likely to have political connections.

Concerning the implications of political connections on firm values, anecdotal evidences 
suggest both positive and negative effects. On one hand, a political connection made it easier for a firm to have a preferential treatment by the government especially in regulated industries, but on the other hand it made a firm involved in conflicts between political parties. Regression analyses indicate that firms with relatively low performance before the election tended to have political connections newly through the election, and that those firms that newly had political connections increased their values. That is, political connections newly generated through the election indeed had a positive effect on firm values. On the other hand, it is notable that experience of a politician director in the political circles deteriorated his positive effect on firm value. The negative impact of the experience almost canceled the positive effect of political connections. This may reflect the negative aspect of having a politician director shown in the anecdote. 
Table1 Number of politically connected firms

Panel A Samples based on Kabushi-kenkan

(1) All firms (Firms for the years 1928 and 1930)

\begin{tabular}{lcccc}
\hline & \multicolumn{1}{c}{ In pre-election period } & & \\
\cline { 2 - 5 } & Non-connected firms & Politically connected firms & Total & $\%$ \\
\hline In post-election period & 899 & 61 & 960 & 84.51 \\
Non-connected firms & 47 & 129 & 176 & 15.49 \\
Politically connected firms & 946 & 190 & 1136 & 100.0 \\
Total & 83.27 & 16.73 & 100.0 & \\
$\%$ & & & & \\
\hline
\end{tabular}

(2) Firms for the year 1928

\begin{tabular}{lcccc}
\hline & \multicolumn{2}{l}{ In pre-election period } & & Total \\
\cline { 2 - 5 } & Non-connected firms & Politically connected firms & $\%$ \\
\hline In post-election period & 433 & 26 & 459 & 82.11 \\
Non-connected firms & 28 & 72 & 100 & 17.89 \\
Politically connected firms & 461 & 98 & 559 & 100.0 \\
Total & 82.47 & 17.53 & 100.0 \\
$\%$ & & & \\
\hline
\end{tabular}

(3) Firms for the year 1930

\begin{tabular}{|c|c|c|c|c|}
\hline & \multicolumn{4}{|l|}{ In pre-election period } \\
\hline & Non-connected firms & Politically connected firms & Total & $\%$ \\
\hline \multicolumn{5}{|l|}{ In post-election period } \\
\hline Non-connected firms & 466 & 35 & 501 & 86.83 \\
\hline Politically connected firms & 19 & 57 & 76 & 13.17 \\
\hline Total & 485 & 92 & 577 & 100.0 \\
\hline$\%$ & 84.06 & 15.94 & 100.0 & \\
\hline
\end{tabular}

Panel B Selected samples in our study

(1) All firms ( Firms for the years 1928 and 1930)

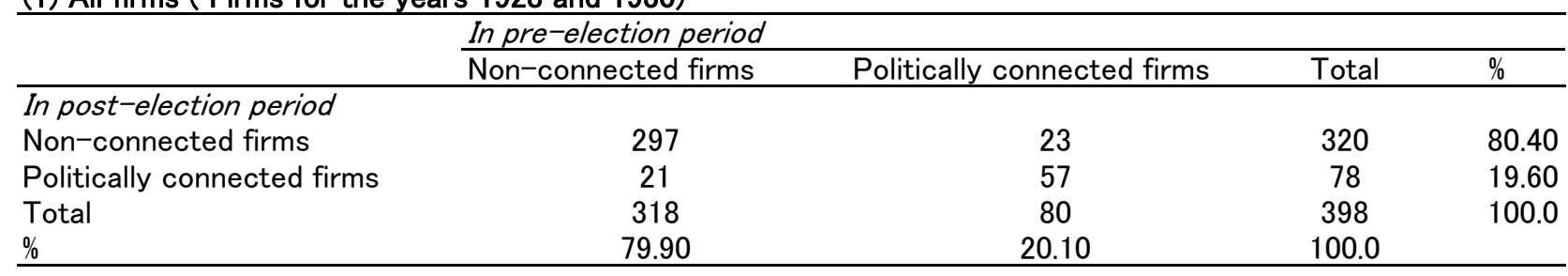

(2) Firms for the year 1928

\begin{tabular}{lcccc}
\hline & \multicolumn{2}{l}{ In pre-election period } & & Total \\
\cline { 2 - 5 } & Non-connected firms & Politically connected firms & $\%$ \\
\hline In post-election period & 142 & 9 & 151 & 77.84 \\
Non-connected firms & 14 & 29 & 43 & 22.16 \\
Politically connected firms & 156 & 38 & 194 & 100.0 \\
Total & 80.41 & 19.59 & 100.0 & \\
$\%$ & & &
\end{tabular}

\section{(3) Firms for the year 1930}

\begin{tabular}{lcccc}
\hline & In pre-election period & & \\
\cline { 2 - 5 } & \multicolumn{2}{c}{ Non-connected firms } & Politically connected firms & Total \\
\hline In post-election period & & & 169 \\
Non-connected firms & 155 & 28 & 82.84 \\
Politically connected firms & 7 & 42 & 35 & 17.16 \\
Total & 162 & 20.59 & 204 & 100.0 \\
$\%$ & 79.41 & & 100.0 & \\
\hline
\end{tabular}


Table2 Distribution of politically connected firms among 13 industries

\begin{tabular}{|c|c|c|c|c|c|}
\hline & Total & & Political connections & & \\
\hline & All firms & Industry share & Non-connected firms & Jolitically connected firms & $\%$ \\
\hline Chemicals & 13 & $3.3 \%$ & 11 & 2 & 15.38 \\
\hline Gas & 12 & $3.0 \%$ & 11 & 1 & 8.33 \\
\hline Mining and Refining & 21 & $5.3 \%$ & 19 & 2 & 9.52 \\
\hline Manufacturing & 45 & $11.3 \%$ & 40 & 5 & 11.11 \\
\hline Sugar & 16 & $4.0 \%$ & 11 & 5 & 31.25 \\
\hline Shipping and Transportation & 19 & $4.8 \%$ & 19 & 0 & 0.00 \\
\hline Railroad & 54 & $13.6 \%$ & 38 & 16 & 29.63 \\
\hline Electric utilities & 40 & $10.1 \%$ & 22 & 18 & 45.00 \\
\hline Exchange & 14 & $3.5 \%$ & 11 & 3 & 21.43 \\
\hline Spinning & 44 & $11.1 \%$ & 36 & 8 & 18.18 \\
\hline Ceramics & 18 & $4.5 \%$ & 14 & 4 & 22.22 \\
\hline Financial institutions & 79 & $19.8 \%$ & 72 & 7 & 8.86 \\
\hline Others & 23 & $5.8 \%$ & 16 & 7 & 30.43 \\
\hline Total & 398 & & 320 & 78 & 19.60 \\
\hline
\end{tabular}


Table 3 political connections by positions of politician directors in firms

Panel A The number of politically connected firms (PCFs) by positions of politician directors

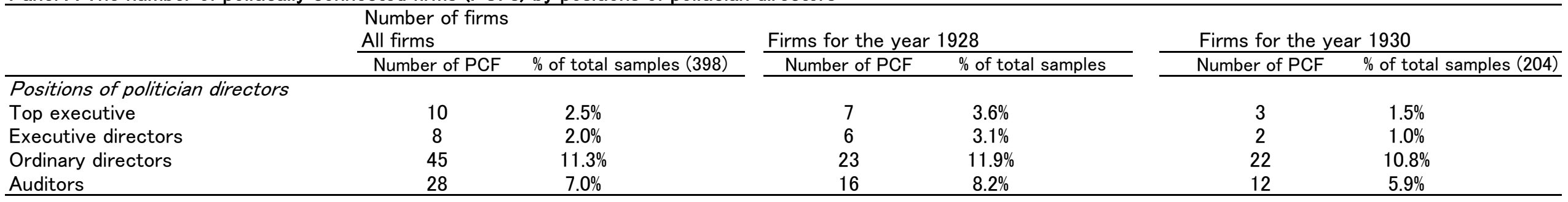

Panel B The number of politician directors (PD) by their positions

\begin{tabular}{|c|c|c|c|c|c|c|c|c|c|}
\hline 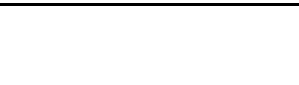 & \multicolumn{3}{|c|}{$\begin{array}{l}\text { Number of directors } \\
\text { Total samples }\end{array}$} & \multicolumn{3}{|c|}{ Firms for the year 1928} & \multicolumn{3}{|c|}{ Firms for the year 1930} \\
\hline & Total & PD & $\%$ & Total & $\mathrm{PD}$ & $\%$ & Total & $\mathrm{PD}$ & $\%$ \\
\hline \multicolumn{10}{|c|}{ Positions of politician directors } \\
\hline Top executive & 375 & 10 & 2.67 & 184 & 7 & 3.80 & 191 & 3 & 1.57 \\
\hline Executive directors & 654 & 9 & 1.38 & 316 & 6 & 1.90 & 338 & 3 & 0.89 \\
\hline Ordinary directors & 2136 & 48 & 2.25 & 1,053 & 24 & 2.28 & 1,083 & 24 & 2.22 \\
\hline Auditors & 1177 & 29 & 2.46 & 569 & 16 & 2.81 & 608 & 13 & 2.14 \\
\hline Total & 4342 & 96 & 2.21 & 2122 & 53 & 2.50 & 2220 & 43 & 1.94 \\
\hline
\end{tabular}


Table4 Descriptive Statistics

\begin{tabular}{|c|c|c|c|c|c|c|}
\hline Variable & \multicolumn{2}{|c|}{ Politically connected } & \multicolumn{4}{|c|}{ Control (Unconnected) } \\
\hline \multicolumn{7}{|l|}{ Stock returns } \\
\hline 1 month & 78 & 1.52 & 297 & 1.27 & -0.234 & 0.815 \\
\hline 2 month & 77 & 0.20 & 296 & 1.00 & 0.509 & 0.611 \\
\hline 3 month & 76 & -1.22 & 291 & -0.83 & 0.212 & 0.832 \\
\hline 4 month & 68 & -2.66 & 250 & -0.99 & 0.865 & 0.388 \\
\hline $\begin{array}{l}5 \text { month } \\
\text { BHR after the election }\end{array}$ & \multicolumn{6}{|c|}{ BHR after the election } \\
\hline 1 month & 78 & -1.15 & 297 & -2.41 & -1.181 & 0.239 \\
\hline 2 month & 77 & -5.39 & 296 & -6.49 & -0.680 & 0.497 \\
\hline 3 month & 76 & -3.70 & 291 & -5.61 & -1.011 & 0.313 \\
\hline 4 month & 68 & -8.81 & 250 & -9.39 & -0.195 & 0.846 \\
\hline 5 month & 68 & -6.98 & 249 & -7.36 & -0.125 & 0.901 \\
\hline \multicolumn{7}{|l|}{ Firm financial variables } \\
\hline Industry-adjusted ROA & 78 & -0.006 & 297 & 0.002 & 1.546 & 0.123 \\
\hline Industry-adjusted Debt ratio & 78 & 0.043 & 297 & -0.013 & -2.448 & 0.015 \\
\hline Firm size & 78 & 10.345 & 297 & 10.502 & 0.891 & 0.373 \\
\hline
\end{tabular}


Table5 Baseline regressions

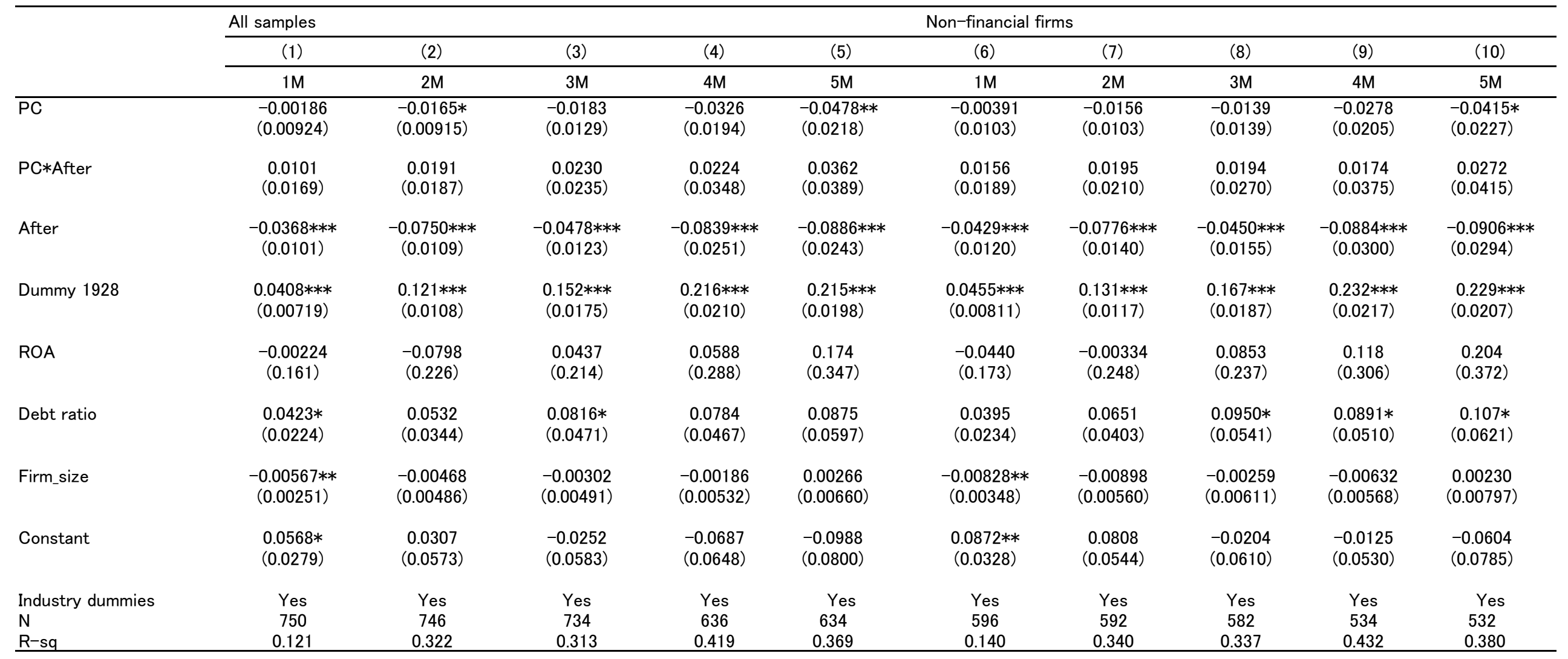


Table 6 The effects of PC in regulated industries

\begin{tabular}{|c|c|c|c|c|c|c|c|c|c|c|}
\hline & \multicolumn{5}{|l|}{ All samples } & \multicolumn{5}{|c|}{ Non-financial firms } \\
\hline & (1) & (2) & (3) & (4) & (5) & (6) & (7) & (8) & (9) & $(10)$ \\
\hline & $1 \mathrm{M}$ & $2 \mathrm{M}$ & $3 \mathrm{M}$ & $4 \mathrm{M}$ & $5 \mathrm{M}$ & $1 \mathrm{M}$ & $2 \mathrm{M}$ & $3 \mathrm{M}$ & $4 \mathrm{M}$ & $5 \mathrm{M}$ \\
\hline $\mathrm{PC}$ & $\begin{array}{c}-0.00216 \\
(0.00935)\end{array}$ & $\begin{array}{c}-0.0115 \\
(0.00945)\end{array}$ & $\begin{array}{l}-0.0154 \\
(0.0127)\end{array}$ & $\begin{array}{c}-0.0362 * \\
(0.0200)\end{array}$ & $\begin{array}{c}-0.0507 * * \\
(0.0233)\end{array}$ & $\begin{array}{c}-0.00313 \\
(0.0104)\end{array}$ & $\begin{array}{l}-0.00909 \\
(0.00987)\end{array}$ & $\begin{array}{c}-0.00969 \\
(0.0136)\end{array}$ & $\begin{array}{l}-0.0288 \\
(0.0202)\end{array}$ & $\begin{array}{l}-0.0405 * \\
(0.0231)\end{array}$ \\
\hline PC*After & $\begin{array}{c}0.0118 \\
(0.0194)\end{array}$ & $\begin{array}{c}0.0214 \\
(0.0205)\end{array}$ & $\begin{array}{c}0.0305 \\
(0.0264)\end{array}$ & $\begin{array}{c}0.0379 \\
(0.0370)\end{array}$ & $\begin{array}{c}0.0533 \\
(0.0455)\end{array}$ & $\begin{array}{c}0.0194 \\
(0.0229)\end{array}$ & $\begin{array}{c}0.0260 \\
(0.0249)\end{array}$ & $\begin{array}{c}0.0335 \\
(0.0325)\end{array}$ & $\begin{array}{c}0.0344 \\
(0.0406)\end{array}$ & $\begin{array}{c}0.0461 \\
(0.0505)\end{array}$ \\
\hline PC*After*Regulation & $\begin{array}{c}-0.00481 \\
(0.0254)\end{array}$ & $\begin{array}{l}-0.0383 \\
(0.0408)\end{array}$ & $\begin{array}{l}-0.0448 \\
(0.0429)\end{array}$ & $\begin{array}{l}-0.0287 \\
(0.0521)\end{array}$ & $\begin{array}{l}-0.0436 \\
(0.0543)\end{array}$ & $\begin{array}{l}-0.0132 \\
(0.0281)\end{array}$ & $\begin{array}{l}-0.0476 \\
(0.0439)\end{array}$ & $\begin{array}{l}-0.0554 \\
(0.0469)\end{array}$ & $\begin{array}{l}-0.0360 \\
(0.0553)\end{array}$ & $\begin{array}{l}-0.0497 \\
(0.0591)\end{array}$ \\
\hline After & $\begin{array}{c}-0.0370 * * * \\
(0.0119)\end{array}$ & $\begin{array}{c}-0.0843 * * * \\
(0.0118)\end{array}$ & $\begin{array}{c}-0.0556 * * * \\
(0.0133)\end{array}$ & $\begin{array}{c}-0.0822 * * * \\
(0.0292)\end{array}$ & $\begin{array}{l}-0.0907 * * * \\
(0.0287)\end{array}$ & $\begin{array}{c}-0.0452 * * * \\
(0.0149)\end{array}$ & $\begin{array}{c}-0.0921 * * * \\
(0.0152)\end{array}$ & $\begin{array}{c}-0.0561 * * * \\
(0.0179)\end{array}$ & $\begin{array}{c}-0.0888 * * \\
(0.0363)\end{array}$ & $\begin{array}{c}-0.0955 * * \\
(0.0361)\end{array}$ \\
\hline After*Regulation & $\begin{array}{l}0.00148 \\
(0.0188)\end{array}$ & $\begin{array}{c}0.0543 * * \\
(0.0213)\end{array}$ & $\begin{array}{l}0.0457 * \\
(0.0261)\end{array}$ & $\begin{array}{c}-0.00925 \\
(0.0553)\end{array}$ & $\begin{array}{c}0.0108 \\
(0.0480)\end{array}$ & $\begin{array}{l}0.00991 \\
(0.0207)\end{array}$ & $\begin{array}{c}0.0639 * * \\
(0.0232)\end{array}$ & $\begin{array}{c}0.0491 \\
(0.0288)\end{array}$ & $\begin{array}{l}0.00160 \\
(0.0589)\end{array}$ & $\begin{array}{c}0.0209 \\
(0.0518)\end{array}$ \\
\hline Dummy 1928 & $\begin{array}{c}0.0408 * * * \\
(0.00715)\end{array}$ & $\begin{array}{c}0.121 * * * \\
(0.0107)\end{array}$ & $\begin{array}{c}0.152 * * * \\
(0.0173)\end{array}$ & $\begin{array}{c}0.217 * * * \\
(0.0213)\end{array}$ & $\begin{array}{l}0.216 * * * \\
(0.0199)\end{array}$ & $\begin{array}{c}0.0455 * * * \\
(0.00812)\end{array}$ & $\begin{array}{c}0.131 * * * \\
(0.0117)\end{array}$ & $\begin{array}{c}0.167 * * * \\
(0.0187)\end{array}$ & $\begin{array}{c}0.232 * * * \\
(0.0218)\end{array}$ & $\begin{array}{l}0.229 * * * \\
(0.0207)\end{array}$ \\
\hline ROA & $\begin{array}{c}-0.00302 \\
(0.163)\end{array}$ & $\begin{array}{c}-0.0868 \\
(0.227)\end{array}$ & $\begin{array}{l}0.0364 \\
(0.216)\end{array}$ & $\begin{array}{l}0.0525 \\
(0.291)\end{array}$ & $\begin{array}{c}0.163 \\
(0.349)\end{array}$ & $\begin{array}{l}-0.0456 \\
(0.174)\end{array}$ & $\begin{array}{c}-0.0119 \\
(0.249)\end{array}$ & $\begin{array}{l}0.0751 \\
(0.239)\end{array}$ & $\begin{array}{c}0.113 \\
(0.309)\end{array}$ & $\begin{array}{c}0.197 \\
(0.375)\end{array}$ \\
\hline Debt ratio & $\begin{array}{l}0.0412 * \\
(0.0223)\end{array}$ & $\begin{array}{c}0.0492 \\
(0.0348)\end{array}$ & $\begin{array}{c}0.0759 \\
(0.0470)\end{array}$ & $\begin{array}{c}0.0726 \\
(0.0486)\end{array}$ & $\begin{array}{c}0.0764 \\
(0.0612)\end{array}$ & $\begin{array}{c}0.0391 \\
(0.0236)\end{array}$ & $\begin{array}{c}0.0633 \\
(0.0397)\end{array}$ & $\begin{array}{l}0.0928 * \\
(0.0533)\end{array}$ & $\begin{array}{l}0.0874 * \\
(0.0504)\end{array}$ & $\begin{array}{c}0.105 * \\
(0.0611)\end{array}$ \\
\hline Firm_size & $\begin{array}{c}-0.00533 * \\
(0.00279)\end{array}$ & $\begin{array}{c}-0.00385 \\
(0.00549)\end{array}$ & $\begin{array}{l}-0.00167 \\
(0.00537)\end{array}$ & $\begin{array}{c}-0.000367 \\
(0.00584)\end{array}$ & $\begin{array}{c}0.00575 \\
(0.00698)\end{array}$ & $\begin{array}{c}-0.00835 * * \\
(0.00355)\end{array}$ & $\begin{array}{r}-0.00929 \\
(0.00569)\end{array}$ & $\begin{array}{c}-0.00292 \\
(0.00624)\end{array}$ & $\begin{array}{l}-0.00656 \\
(0.00584)\end{array}$ & $\begin{array}{c}0.00198 \\
(0.00823)\end{array}$ \\
\hline Constant & $\begin{array}{c}0.0580 * * \\
(0.0262)\end{array}$ & $\begin{array}{c}0.0375 \\
(0.0526)\end{array}$ & $\begin{array}{l}-0.0180 \\
(0.0525)\end{array}$ & $\begin{array}{l}-0.0638 \\
(0.0530)\end{array}$ & $\begin{array}{l}-0.0856 \\
(0.0645)\end{array}$ & $\begin{array}{c}0.0883 * * \\
(0.0337)\end{array}$ & $\begin{array}{c}0.0880 \\
(0.0544)\end{array}$ & $\begin{array}{l}-0.0151 \\
(0.0621)\end{array}$ & $\begin{array}{l}-0.0125 \\
(0.0514)\end{array}$ & $\begin{array}{l}-0.0581 \\
(0.0772)\end{array}$ \\
\hline $\begin{array}{l}\text { Industry dummies } \\
\mathrm{N} \\
\mathrm{R} \text {-sq }\end{array}$ & $\begin{array}{c}\text { Yes } \\
750 \\
0.121 \\
\end{array}$ & $\begin{array}{c}\text { Yes } \\
746 \\
0.329 \\
\end{array}$ & $\begin{array}{c}\text { Yes } \\
734 \\
0.318 \\
\end{array}$ & $\begin{array}{c}\text { Yes } \\
636 \\
0.420 \\
\end{array}$ & $\begin{array}{c}\text { Yes } \\
634 \\
0.373 \\
\end{array}$ & $\begin{array}{c}\text { Yes } \\
596 \\
0.140 \\
\end{array}$ & $\begin{array}{c}\text { Yes } \\
592 \\
0.349 \\
\end{array}$ & $\begin{array}{c}\text { Yes } \\
582 \\
0.342 \\
\end{array}$ & $\begin{array}{c}\text { Yes } \\
534 \\
0.433 \\
\end{array}$ & $\begin{array}{c}\text { Yes } \\
532 \\
0.381 \\
\end{array}$ \\
\hline
\end{tabular}


Table 7 The effects of PC and firm profitability

\begin{tabular}{|c|c|c|c|c|c|c|c|c|c|c|}
\hline & \multicolumn{5}{|l|}{ All samples } & \multicolumn{5}{|c|}{ Non-financial firms } \\
\hline & (1) & (2) & (3) & (4) & $(5)$ & (6) & (7) & (8) & (9) & (10) \\
\hline & $1 \mathrm{M}$ & $2 \mathrm{M}$ & $3 \mathrm{M}$ & $4 \mathrm{M}$ & $5 \mathrm{M}$ & $1 \mathrm{M}$ & $2 \mathrm{M}$ & $3 \mathrm{M}$ & $4 \mathrm{M}$ & $5 \mathrm{M}$ \\
\hline$\overline{P C}$ & $\begin{array}{l}-0.00202 \\
(0.00929)\end{array}$ & $\begin{array}{c}-0.0184 * \\
(0.00983)\end{array}$ & $\begin{array}{c}-0.0196 \\
(0.0130)\end{array}$ & $\begin{array}{c}-0.0328 \\
(0.0196)\end{array}$ & $\begin{array}{l}-0.0493 * * \\
(0.0222)\end{array}$ & $\begin{array}{c}-0.00400 \\
(0.0102)\end{array}$ & $\begin{array}{c}-0.0167 \\
(0.0103)\end{array}$ & $\begin{array}{l}-0.0135 \\
(0.0141)\end{array}$ & $\begin{array}{c}-0.0262 \\
(0.0203)\end{array}$ & $\begin{array}{l}-0.0398 * \\
(0.0226)\end{array}$ \\
\hline PC*After & $\begin{array}{l}0.00518 \\
(0.0165)\end{array}$ & $\begin{array}{c}0.0182 \\
(0.0185)\end{array}$ & $\begin{array}{c}0.0194 \\
(0.0229)\end{array}$ & $\begin{array}{c}0.0187 \\
(0.0343)\end{array}$ & $\begin{array}{c}0.0305 \\
(0.0377)\end{array}$ & $\begin{array}{c}0.0107 \\
(0.0187)\end{array}$ & $\begin{array}{c}0.0178 \\
(0.0214)\end{array}$ & $\begin{array}{c}0.0149 \\
(0.0267)\end{array}$ & $\begin{array}{c}0.0131 \\
(0.0370)\end{array}$ & $\begin{array}{c}0.0217 \\
(0.0409)\end{array}$ \\
\hline $\mathrm{PC} *$ After*ROA & $\begin{array}{l}-1.054 \\
(0.790)\end{array}$ & $\begin{array}{l}-0.885 \\
(0.594)\end{array}$ & $\begin{array}{l}-1.152 \\
(0.784)\end{array}$ & $\begin{array}{l}-0.336 \\
(0.715)\end{array}$ & $\begin{array}{l}-0.836 \\
(1.029)\end{array}$ & $\begin{array}{l}-1.265 \\
(0.845)\end{array}$ & $\begin{array}{c}-1.354 * * \\
(0.576)\end{array}$ & $\begin{array}{c}-1.607 * \\
(0.814)\end{array}$ & $\begin{array}{l}-0.373 \\
(0.767)\end{array}$ & $\begin{array}{l}-0.822 \\
(1.116)\end{array}$ \\
\hline After & $\begin{array}{c}-0.0371 * * * \\
(0.0103)\end{array}$ & $\begin{array}{c}-0.0760 * * * \\
(0.0113)\end{array}$ & $\begin{array}{c}-0.0483 * * * \\
(0.0125)\end{array}$ & $\begin{array}{c}-0.0829 * * * \\
(0.0255)\end{array}$ & $\begin{array}{l}-0.0877 * * * \\
(0.0248)\end{array}$ & $\begin{array}{c}-0.0435 * * * \\
(0.0123)\end{array}$ & $\begin{array}{c}-0.0790 * * * \\
(0.0144)\end{array}$ & $\begin{array}{c}-0.0456 * * * \\
(0.0159)\end{array}$ & $\begin{array}{c}-0.0867 * * * \\
(0.0305)\end{array}$ & $\begin{array}{c}-0.0892 * * * \\
(0.0300)\end{array}$ \\
\hline After*ROA & $\begin{array}{c}0.152 \\
(0.172)\end{array}$ & $\begin{array}{l}0.478 * \\
(0.277)\end{array}$ & $\begin{array}{c}0.182 \\
(0.305)\end{array}$ & $\begin{array}{l}-0.235 \\
(0.342)\end{array}$ & $\begin{array}{l}-0.210 \\
(0.328)\end{array}$ & $\begin{array}{c}0.266 \\
(0.192)\end{array}$ & $\begin{array}{l}0.610 * \\
(0.329)\end{array}$ & $\begin{array}{c}0.199 \\
(0.374)\end{array}$ & $\begin{array}{l}-0.356 \\
(0.392)\end{array}$ & $\begin{array}{l}-0.304 \\
(0.375)\end{array}$ \\
\hline Dummy 1928 & $\begin{array}{c}0.0414 * * * \\
(0.00737)\end{array}$ & $\begin{array}{c}0.122 * * * \\
(0.0110)\end{array}$ & $\begin{array}{c}0.153 * * * \\
(0.0176)\end{array}$ & $\begin{array}{c}0.217 * * * \\
(0.0217)\end{array}$ & $\begin{array}{l}0.217 * * * \\
(0.0205)\end{array}$ & $\begin{array}{c}0.0468 * * * \\
(0.00825)\end{array}$ & $\begin{array}{c}0.132 * * * \\
(0.0119)\end{array}$ & $\begin{array}{c}0.169 * * * \\
(0.0190)\end{array}$ & $\begin{array}{l}0.233 * * * \\
(0.0224)\end{array}$ & $\begin{array}{l}0.230 * * * \\
(0.0217)\end{array}$ \\
\hline ROA & $\begin{array}{c}-0.0149 \\
(0.200)\end{array}$ & $\begin{array}{l}-0.276 \\
(0.274)\end{array}$ & $\begin{array}{c}0.00923 \\
(0.284)\end{array}$ & $\begin{array}{c}0.190 \\
(0.292)\end{array}$ & $\begin{array}{c}0.313 \\
(0.347)\end{array}$ & $\begin{array}{c}-0.0963 \\
(0.215)\end{array}$ & $\begin{array}{l}-0.240 \\
(0.308)\end{array}$ & $\begin{array}{l}0.0668 \\
(0.318)\end{array}$ & $\begin{array}{c}0.315 \\
(0.294)\end{array}$ & $\begin{array}{c}0.397 \\
(0.362)\end{array}$ \\
\hline Debt ratio & $\begin{array}{l}0.0405 * \\
(0.0215)\end{array}$ & $\begin{array}{c}0.0481 \\
(0.0343)\end{array}$ & $\begin{array}{c}0.0746 \\
(0.0465)\end{array}$ & $\begin{array}{c}0.0731 \\
(0.0480)\end{array}$ & $\begin{array}{c}0.0763 \\
(0.0606)\end{array}$ & $\begin{array}{l}0.0387 * \\
(0.0222)\end{array}$ & $\begin{array}{c}0.0613 \\
(0.0391)\end{array}$ & $\begin{array}{l}0.0907 * \\
(0.0527)\end{array}$ & $\begin{array}{l}0.0880 * \\
(0.0498)\end{array}$ & $\begin{array}{c}0.105 * \\
(0.0604)\end{array}$ \\
\hline Firm_size & $\begin{array}{c}-0.00483 * \\
(0.00265)\end{array}$ & $\begin{array}{l}-0.00338 \\
(0.00540)\end{array}$ & $\begin{array}{l}-0.00111 \\
(0.00524)\end{array}$ & $\begin{array}{c}-0.000106 \\
(0.00576)\end{array}$ & $\begin{array}{c}0.00628 \\
(0.00673)\end{array}$ & $\begin{array}{c}-0.00781 * * \\
(0.00325)\end{array}$ & $\begin{array}{l}-0.00863 \\
(0.00551)\end{array}$ & $\begin{array}{l}-0.00223 \\
(0.00605)\end{array}$ & $\begin{array}{l}-0.00627 \\
(0.00568)\end{array}$ & $\begin{array}{c}0.00242 \\
(0.00789)\end{array}$ \\
\hline Constant & $\begin{array}{c}0.0559 * * \\
(0.0251)\end{array}$ & $\begin{array}{c}0.0327 \\
(0.0521)\end{array}$ & $\begin{array}{l}-0.0221 \\
(0.0523)\end{array}$ & $\begin{array}{l}-0.0637 \\
(0.0548)\end{array}$ & $\begin{array}{l}-0.0885 \\
(0.0662)\end{array}$ & $\begin{array}{c}0.0856 * * \\
(0.0307)\end{array}$ & $\begin{array}{c}0.0805 \\
(0.0540)\end{array}$ & $\begin{array}{l}-0.0207 \\
(0.0611)\end{array}$ & $\begin{array}{l}-0.0135 \\
(0.0536)\end{array}$ & $\begin{array}{l}-0.0614 \\
(0.0788)\end{array}$ \\
\hline $\begin{array}{l}\text { Industry dummies } \\
\mathrm{N} \\
\mathrm{R}-\mathrm{sq}\end{array}$ & $\begin{array}{c}\text { Yes } \\
750 \\
0.133\end{array}$ & $\begin{array}{c}\text { Yes } \\
746 \\
0.330\end{array}$ & $\begin{array}{c}\text { Yes } \\
734 \\
0.319\end{array}$ & $\begin{array}{c}\text { Yes } \\
636 \\
0.421\end{array}$ & $\begin{array}{l}\text { Yes } \\
634 \\
0.375\end{array}$ & $\begin{array}{c}\text { Yes } \\
596 \\
0.158\end{array}$ & $\begin{array}{c}\text { Yes } \\
592 \\
0.353\end{array}$ & $\begin{array}{c}\text { Yes } \\
582 \\
0.346\end{array}$ & $\begin{array}{c}\text { Yes } \\
534 \\
0.434\end{array}$ & $\begin{array}{c}\text { Yes } \\
532 \\
0.383\end{array}$ \\
\hline
\end{tabular}


Table 8 The effects of $P C$ and firm risk

\begin{tabular}{|c|c|c|c|c|c|c|c|c|c|c|}
\hline & \multicolumn{5}{|l|}{ All samples } & \multicolumn{5}{|c|}{ Non-financial firms } \\
\hline & (1) & (2) & (3) & (4) & (5) & (6) & (7) & (8) & (9) & (10) \\
\hline & $1 \mathrm{M}$ & $2 \mathrm{M}$ & $3 \mathrm{M}$ & $4 \mathrm{M}$ & $5 \mathrm{M}$ & $1 \mathrm{M}$ & $2 \mathrm{M}$ & $3 \mathrm{M}$ & $4 \mathrm{M}$ & $5 \mathrm{M}$ \\
\hline$\overline{\mathrm{PC}}$ & $\begin{array}{l}-0.00307 \\
(0.00945)\end{array}$ & $\begin{array}{c}-0.0194 * \\
(0.0100)\end{array}$ & $\begin{array}{l}-0.0201 \\
(0.0138)\end{array}$ & $\begin{array}{l}-0.0328 \\
(0.0204)\end{array}$ & $\begin{array}{l}-0.0488 * * \\
(0.0228)\end{array}$ & $\begin{array}{c}-0.00499 \\
(0.0105)\end{array}$ & $\begin{array}{l}-0.0182 \\
(0.0107)\end{array}$ & $\begin{array}{l}-0.0139 \\
(0.0151)\end{array}$ & $\begin{array}{l}-0.0259 \\
(0.0211)\end{array}$ & $\begin{array}{l}-0.0391 \\
(0.0233)\end{array}$ \\
\hline PC*After & $\begin{array}{c}0.0128 \\
(0.0176)\end{array}$ & $\begin{array}{c}0.0181 \\
(0.0188)\end{array}$ & $\begin{array}{c}0.0147 \\
(0.0245)\end{array}$ & $\begin{array}{c}0.0142 \\
(0.0364)\end{array}$ & $\begin{array}{c}0.0194 \\
(0.0374)\end{array}$ & $\begin{array}{c}0.0176 \\
(0.0196)\end{array}$ & $\begin{array}{c}0.0167 \\
(0.0213)\end{array}$ & $\begin{array}{l}0.00849 \\
(0.0280)\end{array}$ & $\begin{array}{l}0.00824 \\
(0.0392)\end{array}$ & $\begin{array}{c}0.0113 \\
(0.0404)\end{array}$ \\
\hline PC*After*Debt_ratio & $\begin{array}{l}-0.0243 \\
(0.0988)\end{array}$ & $\begin{array}{c}0.136 \\
(0.135)\end{array}$ & $\begin{array}{c}0.249 \\
(0.174)\end{array}$ & $\begin{array}{c}0.149 \\
(0.190)\end{array}$ & $\begin{array}{c}0.339 \\
(0.280)\end{array}$ & $\begin{array}{c}0.00496 \\
(0.112)\end{array}$ & $\begin{array}{c}0.234 \\
(0.147)\end{array}$ & $\begin{array}{c}0.334 \\
(0.200)\end{array}$ & $\begin{array}{c}0.157 \\
(0.207)\end{array}$ & $\begin{array}{c}0.331 \\
(0.307)\end{array}$ \\
\hline After & $\begin{array}{c}-0.0372 * * * \\
(0.0103)\end{array}$ & $\begin{array}{c}-0.0761 * * * \\
(0.0114)\end{array}$ & $\begin{array}{c}-0.0484 * * * \\
(0.0127)\end{array}$ & $\begin{array}{c}-0.0835 * * * \\
(0.0252)\end{array}$ & $\begin{array}{c}-0.0881 * * * \\
(0.0248)\end{array}$ & $\begin{array}{c}-0.0435 * * * \\
(0.0123)\end{array}$ & $\begin{array}{c}-0.0793 * * * \\
(0.0145)\end{array}$ & $\begin{array}{c}-0.0456 * * \\
(0.0163)\end{array}$ & $\begin{array}{c}-0.0875 * * * \\
(0.0302)\end{array}$ & $\begin{array}{c}-0.0897 * * * \\
(0.0302)\end{array}$ \\
\hline After*Debt_ratio & $\begin{array}{c}0.0409 * * * \\
(0.00711)\end{array}$ & $\begin{array}{c}0.121 * * * \\
(0.0105)\end{array}$ & $\begin{array}{c}0.151 * * * \\
(0.0170)\end{array}$ & $\begin{array}{c}0.217 * * * \\
(0.0211)\end{array}$ & $\begin{array}{c}0.216 * * * \\
(0.0196)\end{array}$ & $\begin{array}{c}0.0455 * * * \\
(0.00811)\end{array}$ & $\begin{array}{c}0.131 * * * \\
(0.0114)\end{array}$ & $\begin{array}{c}0.167 * * * \\
(0.0183)\end{array}$ & $\begin{array}{c}0.232 * * * \\
(0.0216)\end{array}$ & $\begin{array}{l}0.229 * * * \\
(0.0204)\end{array}$ \\
\hline Dummy 1928 & $\begin{array}{l}-0.0297 \\
(0.0393)\end{array}$ & $\begin{array}{l}-0.0895 \\
(0.0667)\end{array}$ & $\begin{array}{c}-0.0432 \\
(0.0845)\end{array}$ & $\begin{array}{c}0.0278 \\
(0.0924)\end{array}$ & $\begin{array}{c}0.0337 \\
(0.0878)\end{array}$ & $\begin{array}{l}-0.0419 \\
(0.0501)\end{array}$ & $\begin{array}{c}-0.126 \\
(0.0812)\end{array}$ & $\begin{array}{c}-0.0422 \\
(0.112)\end{array}$ & $\begin{array}{l}0.0504 \\
(0.110)\end{array}$ & $\begin{array}{l}0.0482 \\
(0.107)\end{array}$ \\
\hline ROA & $\begin{array}{c}-0.00209 \\
(0.161)\end{array}$ & $\begin{array}{c}-0.0788 \\
(0.226)\end{array}$ & $\begin{array}{l}0.0457 \\
(0.214)\end{array}$ & $\begin{array}{l}0.0542 \\
(0.290)\end{array}$ & $\begin{array}{c}0.164 \\
(0.352)\end{array}$ & $\begin{array}{c}-0.0440 \\
(0.173)\end{array}$ & $\begin{array}{c}0.000394 \\
(0.248)\end{array}$ & $\begin{array}{l}0.0889 \\
(0.237)\end{array}$ & $\begin{array}{c}0.120 \\
(0.308)\end{array}$ & $\begin{array}{c}0.207 \\
(0.377)\end{array}$ \\
\hline Debt ratio & $\begin{array}{c}0.0577 * * \\
(0.0272)\end{array}$ & $\begin{array}{c}0.0875 \\
(0.0568)\end{array}$ & $\begin{array}{c}0.0848 \\
(0.0795)\end{array}$ & $\begin{array}{c}0.0508 \\
(0.0722)\end{array}$ & $\begin{array}{c}0.0407 \\
(0.0801)\end{array}$ & $\begin{array}{l}0.0601 * \\
(0.0313)\end{array}$ & $\begin{array}{c}0.114 \\
(0.0673)\end{array}$ & $\begin{array}{c}0.0957 \\
(0.0982)\end{array}$ & $\begin{array}{c}0.0538 \\
(0.0836)\end{array}$ & $\begin{array}{c}0.0619 \\
(0.0895)\end{array}$ \\
\hline Firm_size & $\begin{array}{c}-0.00530 * \\
(0.00275)\end{array}$ & $\begin{array}{l}-0.00379 \\
(0.00554)\end{array}$ & $\begin{array}{l}-0.00170 \\
(0.00534)\end{array}$ & $\begin{array}{c}-0.000426 \\
(0.00593)\end{array}$ & $\begin{array}{c}0.00552 \\
(0.00702)\end{array}$ & $\begin{array}{c}-0.00829 * * \\
(0.00355)\end{array}$ & $\begin{array}{l}-0.00978 \\
(0.00578)\end{array}$ & $\begin{array}{l}-0.00385 \\
(0.00632)\end{array}$ & $\begin{array}{l}-0.00698 \\
(0.00618)\end{array}$ & $\begin{array}{l}0.000907 \\
(0.00865)\end{array}$ \\
\hline Constant & $\begin{array}{c}0.0581 * * \\
(0.0258)\end{array}$ & $\begin{array}{c}0.0344 \\
(0.0530)\end{array}$ & $\begin{array}{l}-0.0196 \\
(0.0524)\end{array}$ & $\begin{array}{l}-0.0624 \\
(0.0554)\end{array}$ & $\begin{array}{l}-0.0856 \\
(0.0665)\end{array}$ & $\begin{array}{c}0.0876 * * \\
(0.0337)\end{array}$ & $\begin{array}{c}0.0884 \\
(0.0564)\end{array}$ & $\begin{array}{c}-0.00919 \\
(0.0633)\end{array}$ & $\begin{array}{c}-0.00844 \\
(0.0561)\end{array}$ & $\begin{array}{l}-0.0512 \\
(0.0824)\end{array}$ \\
\hline $\begin{array}{l}\text { Industry dummies } \\
\mathrm{N} \\
\mathrm{R} \text {-sq }\end{array}$ & $\begin{array}{c}\text { Yes } \\
750 \\
0.122 \\
\end{array}$ & $\begin{array}{c}\text { Yes } \\
746 \\
0.327 \\
\end{array}$ & $\begin{array}{c}\text { Yes } \\
734 \\
0.320 \\
\end{array}$ & $\begin{array}{c}\text { Yes } \\
636 \\
0.421 \\
\end{array}$ & $\begin{array}{c}\text { Yes } \\
634 \\
0.378 \\
\end{array}$ & $\begin{array}{c}\text { Yes } \\
596 \\
0.141 \\
\end{array}$ & $\begin{array}{c}\text { Yes } \\
592 \\
0.349 \\
\end{array}$ & $\begin{array}{c}\text { Yes } \\
582 \\
0.345 \\
\end{array}$ & $\begin{array}{c}\text { Yes } \\
534 \\
0.434 \\
\end{array}$ & $\begin{array}{c}\text { Yes } \\
532 \\
0.386 \\
\end{array}$ \\
\hline
\end{tabular}




\begin{tabular}{|c|c|c|c|c|c|c|c|c|c|c|}
\hline & \multicolumn{5}{|l|}{ All samples } & \multicolumn{5}{|c|}{ Non-financial firms } \\
\hline & (1) & (2) & (3) & (4) & (5) & (6) & (7) & (8) & (9) & (10) \\
\hline & $1 \mathrm{M}$ & $2 \mathrm{M}$ & $3 \mathrm{M}$ & $4 \mathrm{M}$ & $5 \mathrm{M}$ & $1 \mathrm{M}$ & $2 \mathrm{M}$ & $3 \mathrm{M}$ & $4 \mathrm{M}$ & $5 \mathrm{M}$ \\
\hline$\overline{P C}$ & $\begin{array}{l}-0.00179 \\
(0.00939)\end{array}$ & $\begin{array}{c}-0.0169 * \\
(0.00972)\end{array}$ & $\begin{array}{l}-0.0194 \\
(0.0128)\end{array}$ & $\begin{array}{c}-0.0337 * \\
(0.0196)\end{array}$ & $\begin{array}{l}-0.0504 * * \\
(0.0221)\end{array}$ & $\begin{array}{c}-0.00360 \\
(0.0104)\end{array}$ & $\begin{array}{l}-0.0153 \\
(0.0104)\end{array}$ & $\begin{array}{l}-0.0137 \\
(0.0140)\end{array}$ & $\begin{array}{l}-0.0277 \\
(0.0205)\end{array}$ & $\begin{array}{l}-0.0413 * \\
(0.0227)\end{array}$ \\
\hline PC*After & $\begin{array}{c}0.0811 * * \\
(0.0321)\end{array}$ & $\begin{array}{c}0.0936 * * * \\
(0.0247)\end{array}$ & $\begin{array}{c}0.0638 * * * \\
(0.0218)\end{array}$ & $\begin{array}{c}0.0923 * * \\
(0.0380)\end{array}$ & $\begin{array}{l}0.0910 \\
(0.108)\end{array}$ & $\begin{array}{c}0.0848 * * \\
(0.0325)\end{array}$ & $\begin{array}{c}0.0926 * * * \\
(0.0248)\end{array}$ & $\begin{array}{c}0.0558 * * \\
(0.0226)\end{array}$ & $\begin{array}{c}0.0864 * * \\
(0.0380)\end{array}$ & $\begin{array}{l}0.0801 \\
(0.106)\end{array}$ \\
\hline PC*After*Experience & $\begin{array}{c}-0.0780 * * \\
(0.0300)\end{array}$ & $\begin{array}{c}-0.0820 * * \\
(0.0309)\end{array}$ & $\begin{array}{c}-0.0449 * \\
(0.0231)\end{array}$ & $\begin{array}{c}-0.0767 * \\
(0.0436)\end{array}$ & $\begin{array}{c}-0.0601 \\
(0.112)\end{array}$ & $\begin{array}{c}-0.0768 * * \\
(0.0304)\end{array}$ & $\begin{array}{c}-0.0813 * * \\
(0.0310)\end{array}$ & $\begin{array}{c}-0.0405 * \\
(0.0233)\end{array}$ & $\begin{array}{c}-0.0762 * \\
(0.0434)\end{array}$ & $\begin{array}{c}-0.0584 \\
(0.111)\end{array}$ \\
\hline After & $\begin{array}{c}-0.0368 * * * \\
(0.0101)\end{array}$ & $\begin{array}{c}-0.0750 * * * \\
(0.0109)\end{array}$ & $\begin{array}{c}-0.0478 * * * \\
(0.0123)\end{array}$ & $\begin{array}{c}-0.0839 * * * \\
(0.0251)\end{array}$ & $\begin{array}{l}-0.0886 * * * \\
(0.0243)\end{array}$ & $\begin{array}{c}-0.0429 * * * \\
(0.0120)\end{array}$ & $\begin{array}{c}-0.0776 * * * \\
(0.0140)\end{array}$ & $\begin{array}{c}-0.0450 * * * \\
(0.0156)\end{array}$ & $\begin{array}{c}-0.0884 * * * \\
(0.0300)\end{array}$ & $\begin{array}{l}-0.0906 * * * \\
(0.0295)\end{array}$ \\
\hline Dummy 1928 & $\begin{array}{c}0.0407 * * * \\
(0.00716)\end{array}$ & $\begin{array}{c}0.121 * * * \\
(0.0105)\end{array}$ & $\begin{array}{c}0.152 * * * \\
(0.0172)\end{array}$ & $\begin{array}{c}0.217 * * * \\
(0.0210)\end{array}$ & $\begin{array}{l}0.216 * * * \\
(0.0196)\end{array}$ & $\begin{array}{c}0.0453 * * * \\
(0.00813)\end{array}$ & $\begin{array}{c}0.130 * * * \\
(0.0114)\end{array}$ & $\begin{array}{c}0.167 * * * \\
(0.0186)\end{array}$ & $\begin{array}{l}0.232 * * * \\
(0.0215)\end{array}$ & $\begin{array}{l}0.229 * * * \\
(0.0203)\end{array}$ \\
\hline ROA & $\begin{array}{l}0.00320 \\
(0.162)\end{array}$ & $\begin{array}{c}-0.0731 \\
(0.226)\end{array}$ & $\begin{array}{l}0.0485 \\
(0.214)\end{array}$ & $\begin{array}{l}0.0637 \\
(0.289)\end{array}$ & $\begin{array}{c}0.175 \\
(0.347)\end{array}$ & $\begin{array}{c}-0.0380 \\
(0.174)\end{array}$ & $\begin{array}{l}0.00403 \\
(0.249)\end{array}$ & $\begin{array}{l}0.0891 \\
(0.238)\end{array}$ & $\begin{array}{c}0.126 \\
(0.308)\end{array}$ & $\begin{array}{c}0.210 \\
(0.374)\end{array}$ \\
\hline Debt ratio & $\begin{array}{l}0.0408 * \\
(0.0222)\end{array}$ & $\begin{array}{c}0.0501 \\
(0.0354)\end{array}$ & $\begin{array}{c}0.0774 \\
(0.0478)\end{array}$ & $\begin{array}{c}0.0741 \\
(0.0491)\end{array}$ & $\begin{array}{c}0.0786 \\
(0.0621)\end{array}$ & $\begin{array}{c}0.0386 \\
(0.0235)\end{array}$ & $\begin{array}{c}0.0643 \\
(0.0405)\end{array}$ & $\begin{array}{l}0.0946 * \\
(0.0544)\end{array}$ & $\begin{array}{l}0.0892 * \\
(0.0513)\end{array}$ & $\begin{array}{c}0.107 * \\
(0.0624)\end{array}$ \\
\hline Firm_size & $\begin{array}{c}-0.00522 * \\
(0.00275)\end{array}$ & $\begin{array}{l}-0.00362 \\
(0.00544)\end{array}$ & $\begin{array}{l}-0.00147 \\
(0.00533)\end{array}$ & $\begin{array}{c}-0.000213 \\
(0.00573)\end{array}$ & $\begin{array}{c}0.00595 \\
(0.00683)\end{array}$ & $\begin{array}{c}-0.00818 * * \\
(0.00348)\end{array}$ & $\begin{array}{l}-0.00887 \\
(0.00559)\end{array}$ & $\begin{array}{l}-0.00252 \\
(0.00613)\end{array}$ & $\begin{array}{l}-0.00629 \\
(0.00569)\end{array}$ & $\begin{array}{c}0.00232 \\
(0.00799)\end{array}$ \\
\hline Constant & $\begin{array}{l}0.0581 * * \\
(0.0257)\end{array}$ & $\begin{array}{c}0.0337 \\
(0.0521)\end{array}$ & $\begin{array}{l}-0.0208 \\
(0.0524)\end{array}$ & $\begin{array}{l}-0.0614 \\
(0.0541)\end{array}$ & $\begin{array}{l}-0.0850 \\
(0.0655)\end{array}$ & $\begin{array}{c}0.0874 * * \\
(0.0327)\end{array}$ & $\begin{array}{c}0.0809 \\
(0.0541)\end{array}$ & $\begin{array}{l}-0.0205 \\
(0.0609)\end{array}$ & $\begin{array}{l}-0.0113 \\
(0.0529)\end{array}$ & $\begin{array}{l}-0.0595 \\
(0.0779)\end{array}$ \\
\hline Industry dummies & Yes & Yes & Yes & Yes & Yes & Yes & Yes & Yes & Yes & Yes \\
\hline $\mathrm{N}$ & 750 & 746 & 734 & 636 & 634 & 596 & 592 & 582 & 534 & 532 \\
\hline $\mathrm{R}-\mathrm{sq}$ & 0.128 & 0.326 & 0.316 & 0.421 & 0.373 & 0.147 & 0.344 & 0.338 & 0.433 & 0.381 \\
\hline
\end{tabular}




\begin{tabular}{|c|c|c|c|c|c|c|c|c|c|c|}
\hline & \multicolumn{5}{|l|}{ All samples } & \multicolumn{5}{|c|}{ Non-financial firms } \\
\hline & $(1)$ & (2) & (3) & (4) & (5) & $(6)$ & (7) & (8) & (9) & (10) \\
\hline & $1 \mathrm{M}$ & $2 \mathrm{M}$ & $3 \mathrm{M}$ & $4 M$ & $5 M$ & $1 \mathrm{M}$ & $2 M$ & $3 M$ & $4 \mathrm{M}$ & $5 \mathrm{M}$ \\
\hline$\overline{\mathrm{PC} 01}$ & $\begin{array}{c}-0.00626 \\
(0.0183)\end{array}$ & $\begin{array}{c}-0.0349 * * \\
(0.0147)\end{array}$ & $\begin{array}{c}-0.0373 * \\
(0.0198)\end{array}$ & $\begin{array}{c}-0.0865 * * \\
(0.0350)\end{array}$ & $\begin{array}{l}-0.103 * * \\
(0.0387)\end{array}$ & $\begin{array}{c}-0.00589 \\
(0.0216)\end{array}$ & $\begin{array}{c}-0.0338 * \\
(0.0173)\end{array}$ & $\begin{array}{l}-0.0357 \\
(0.0238)\end{array}$ & $\begin{array}{c}-0.0803 * \\
(0.0398)\end{array}$ & $\begin{array}{l}-0.0900 * * \\
(0.0427)\end{array}$ \\
\hline PC11 & $\begin{array}{c}-0.000796 \\
(0.0107)\end{array}$ & $\begin{array}{l}-0.0110 \\
(0.0108)\end{array}$ & $\begin{array}{c}-0.0124 \\
(0.0134)\end{array}$ & $\begin{array}{l}-0.0151 \\
(0.0204)\end{array}$ & $\begin{array}{l}-0.0305 \\
(0.0226)\end{array}$ & $\begin{array}{c}-0.00333 \\
(0.0116)\end{array}$ & $\begin{array}{l}-0.0101 \\
(0.0116)\end{array}$ & $\begin{array}{c}-0.00628 \\
(0.0140)\end{array}$ & $\begin{array}{l}-0.0110 \\
(0.0212)\end{array}$ & $\begin{array}{l}-0.0247 \\
(0.0238)\end{array}$ \\
\hline PC10 & $\begin{array}{c}0.00467 \\
(0.00910)\end{array}$ & $\begin{array}{l}-0.0261 \\
(0.0190)\end{array}$ & $\begin{array}{l}-0.0259 \\
(0.0287)\end{array}$ & $\begin{array}{c}-0.00307 \\
(0.0307)\end{array}$ & $\begin{array}{l}-0.0268 \\
(0.0347)\end{array}$ & $\begin{array}{l}0.00443 \\
(0.0102)\end{array}$ & $\begin{array}{l}-0.0261 \\
(0.0208)\end{array}$ & $\begin{array}{l}-0.0250 \\
(0.0319)\end{array}$ & $\begin{array}{c}-0.000691 \\
(0.0324)\end{array}$ & $\begin{array}{l}-0.0254 \\
(0.0376)\end{array}$ \\
\hline PC01*After & $\begin{array}{c}0.0352 \\
(0.0242)\end{array}$ & $\begin{array}{c}0.0559 * * \\
(0.0214)\end{array}$ & $\begin{array}{c}0.0558 * * \\
(0.0224)\end{array}$ & $\begin{array}{c}0.135 * * * \\
(0.0425)\end{array}$ & $\begin{array}{c}0.127 * * \\
(0.0580)\end{array}$ & $\begin{array}{c}0.0395 \\
(0.0282)\end{array}$ & $\begin{array}{c}0.0557 * * \\
(0.0253)\end{array}$ & $\begin{array}{l}0.0541 * \\
(0.0272)\end{array}$ & $\begin{array}{l}0.135 * * \\
(0.0489)\end{array}$ & $\begin{array}{c}0.117 * \\
(0.0660)\end{array}$ \\
\hline PC11*After & $\begin{array}{c}0.000854 \\
(0.0200)\end{array}$ & $\begin{array}{l}0.00525 \\
(0.0225)\end{array}$ & $\begin{array}{c}0.0105 \\
(0.0278)\end{array}$ & $\begin{array}{c}-0.0152 \\
(0.0394)\end{array}$ & $\begin{array}{l}0.00603 \\
(0.0435)\end{array}$ & $\begin{array}{l}0.00748 \\
(0.0217)\end{array}$ & $\begin{array}{l}0.00694 \\
(0.0246)\end{array}$ & $\begin{array}{l}0.00721 \\
(0.0311)\end{array}$ & $\begin{array}{l}-0.0187 \\
(0.0418)\end{array}$ & $\begin{array}{c}-0.000473 \\
(0.0462)\end{array}$ \\
\hline PC10*After & $\begin{array}{l}-0.0148 \\
(0.0161)\end{array}$ & $\begin{array}{c}0.000996 \\
(0.0203)\end{array}$ & $\begin{array}{l}0.00334 \\
(0.0324)\end{array}$ & $\begin{array}{c}-0.0491 \\
(0.0378)\end{array}$ & $\begin{array}{l}-0.0287 \\
(0.0400)\end{array}$ & $\begin{array}{l}-0.0130 \\
(0.0179)\end{array}$ & $\begin{array}{l}0.00135 \\
(0.0234)\end{array}$ & $\begin{array}{c}-0.000375 \\
(0.0369)\end{array}$ & $\begin{array}{l}-0.0522 \\
(0.0420)\end{array}$ & $\begin{array}{c}-0.0319 \\
(0.0448)\end{array}$ \\
\hline After & $\begin{array}{c}-0.0368 * * * \\
(0.0101)\end{array}$ & $\begin{array}{c}-0.0750 * * * \\
(0.0109)\end{array}$ & $\begin{array}{c}-0.0478 * * * \\
(0.0123)\end{array}$ & $\begin{array}{c}-0.0839 * * * \\
(0.0252)\end{array}$ & $\begin{array}{l}-0.0886 * * * \\
(0.0244)\end{array}$ & $\begin{array}{c}-0.0429 * * * \\
(0.0120)\end{array}$ & $\begin{array}{c}-0.0776 * * * \\
(0.0140)\end{array}$ & $\begin{array}{c}-0.0450 * * * \\
(0.0156)\end{array}$ & $\begin{array}{c}-0.0884 * * * \\
(0.0301)\end{array}$ & $\begin{array}{c}-0.0906 * * * \\
(0.0295)\end{array}$ \\
\hline Dummy 1928 & $\begin{array}{c}0.0402 * * * \\
(0.00716)\end{array}$ & $\begin{array}{c}0.120 * * * \\
(0.0112)\end{array}$ & $\begin{array}{c}0.151 * * * \\
(0.0179)\end{array}$ & $\begin{array}{c}0.217 * * * \\
(0.0216)\end{array}$ & $\begin{array}{l}0.217 * * * \\
(0.0203)\end{array}$ & $\begin{array}{c}0.0444 * * * \\
(0.00819)\end{array}$ & $\begin{array}{c}0.129 * * * \\
(0.0124)\end{array}$ & $\begin{array}{c}0.166 * * * \\
(0.0197)\end{array}$ & $\begin{array}{c}0.231 * * * \\
(0.0224)\end{array}$ & $\begin{array}{l}0.228 * * * \\
(0.0215)\end{array}$ \\
\hline ROA & $\begin{array}{l}0.0316 \\
(0.155)\end{array}$ & $\begin{array}{l}0.0561 \\
(0.294)\end{array}$ & $\begin{array}{c}0.236 \\
(0.317)\end{array}$ & $\begin{array}{c}0.297 \\
(0.406)\end{array}$ & $\begin{array}{c}0.411 \\
(0.444)\end{array}$ & $\begin{array}{c}-0.00343 \\
(0.167)\end{array}$ & $\begin{array}{c}0.134 \\
(0.312)\end{array}$ & $\begin{array}{c}0.287 \\
(0.342)\end{array}$ & $\begin{array}{c}0.361 \\
(0.421)\end{array}$ & $\begin{array}{c}0.459 \\
(0.469)\end{array}$ \\
\hline Debt ratio & $\begin{array}{l}0.0430 * \\
(0.0224)\end{array}$ & $\begin{array}{c}0.0564 \\
(0.0351)\end{array}$ & $\begin{array}{l}0.0858 * \\
(0.0466)\end{array}$ & $\begin{array}{l}0.0865 * \\
(0.0506)\end{array}$ & $\begin{array}{c}0.0887 \\
(0.0600)\end{array}$ & $\begin{array}{c}0.0409 \\
(0.0239)\end{array}$ & $\begin{array}{l}0.0695 * \\
(0.0396)\end{array}$ & $\begin{array}{c}0.102 * \\
(0.0524)\end{array}$ & $\begin{array}{c}0.0992 * \\
(0.0522)\end{array}$ & $\begin{array}{c}0.115 * \\
(0.0597)\end{array}$ \\
\hline Firm_size & $\begin{array}{c}-0.00498 * \\
(0.00269)\end{array}$ & $\begin{array}{l}-0.00290 \\
(0.00544)\end{array}$ & $\begin{array}{c}-0.000414 \\
(0.00540)\end{array}$ & $\begin{array}{l}0.000691 \\
(0.00579)\end{array}$ & $\begin{array}{c}0.00708 \\
(0.00665)\end{array}$ & $\begin{array}{c}-0.00780 * * \\
(0.00351)\end{array}$ & $\begin{array}{l}-0.00833 \\
(0.00551)\end{array}$ & $\begin{array}{l}-0.00211 \\
(0.00609)\end{array}$ & $\begin{array}{l}-0.00561 \\
(0.00538)\end{array}$ & $\begin{array}{c}0.00305 \\
(0.00739)\end{array}$ \\
\hline Constant & $\begin{array}{c}0.0560 * * \\
(0.0247)\end{array}$ & $\begin{array}{c}0.0261 \\
(0.0521)\end{array}$ & $\begin{array}{l}-0.0317 \\
(0.0527)\end{array}$ & $\begin{array}{l}-0.0724 \\
(0.0546)\end{array}$ & $\begin{array}{l}-0.0997 \\
(0.0627)\end{array}$ & $\begin{array}{c}0.0842 * * \\
(0.0325)\end{array}$ & $\begin{array}{c}0.0753 \\
(0.0532)\end{array}$ & $\begin{array}{l}-0.0249 \\
(0.0601)\end{array}$ & $\begin{array}{l}-0.0186 \\
(0.0491)\end{array}$ & $\begin{array}{l}-0.0685 \\
(0.0707)\end{array}$ \\
\hline $\begin{array}{l}\text { Industry dummies } \\
\mathrm{N} \\
\mathrm{R}-\mathrm{sq}\end{array}$ & $\begin{array}{c}\text { Yes } \\
796 \\
0.128\end{array}$ & $\begin{array}{c}\text { Yes } \\
792 \\
0329\end{array}$ & $\begin{array}{c}\text { Yes } \\
780 \\
0318\end{array}$ & $\begin{array}{l}\text { Yes } \\
680 \\
0436\end{array}$ & $\begin{array}{l}\text { Yes } \\
678 \\
0.389\end{array}$ & $\begin{array}{c}\text { Yes } \\
638 \\
0146\end{array}$ & $\begin{array}{c}\text { Yes } \\
634 \\
0345\end{array}$ & $\begin{array}{c}\text { Yes } \\
624 \\
0339\end{array}$ & $\begin{array}{c}\text { Yes } \\
576 \\
0447\end{array}$ & $\begin{array}{c}\text { Yes } \\
574 \\
0395\end{array}$ \\
\hline
\end{tabular}


Appendix Table1 Distribution of politically connected firms among 13 industries, based on Kabushi-nenkan

\begin{tabular}{|c|c|c|c|c|c|}
\hline & Total & & \multicolumn{3}{|l|}{ Political connections } \\
\hline & All firms & Industry share & Non-connected firms & Politically connected firms & $\%$ \\
\hline Chemicals & 38 & $3.3 \%$ & 34 & 4 & 10.53 \\
\hline Gas & 34 & $3.0 \%$ & 33 & 1 & 2.94 \\
\hline Mining and Refining & 52 & $4.6 \%$ & 46 & 6 & 11.54 \\
\hline Manufacturing & 110 & $9.7 \%$ & 98 & 12 & 10.91 \\
\hline Sugar & 26 & $2.3 \%$ & 19 & 7 & 26.92 \\
\hline Shipping and Transportation & 52 & $4.6 \%$ & 45 & 7 & 13.46 \\
\hline Railroad & 130 & $11.4 \%$ & 100 & 30 & 23.08 \\
\hline Electric utilities & 100 & $8.8 \%$ & 72 & 28 & 28.00 \\
\hline Exchange & 40 & $3.5 \%$ & 34 & 6 & 15.00 \\
\hline Spinning & 111 & $9.8 \%$ & 99 & 12 & 10.81 \\
\hline Ceramics & 34 & $3.0 \%$ & 28 & 6 & 17.65 \\
\hline Financial institutions & 236 & $20.8 \%$ & 215 & 22 & 9.32 \\
\hline Others & 173 & $15.2 \%$ & 138 & 35 & 20.23 \\
\hline Total & 1136 & $100.0 \%$ & 961 & 176 & 15.49 \\
\hline
\end{tabular}

